\title{
GGE-BIPLOT OF MULTIVARIATE INDEX TO SELECT MAIZE PROGENIES FOR EFFICIENT ASSOCIATION WITH Azospirillum brasiliense ${ }^{1}$
}

\author{
FELIPE CECCON ${ }^{2 *}$, LIVIA MARIA CHAMMA DAVIDE ${ }^{2}$, MANOEL CARLOS GONÇALVES ${ }^{2}$, ADRIANO DOS \\ SANTOS $^{3}$, ELAINE PINHEIRO REIS LOURENTE ${ }^{2}$
}

\begin{abstract}
Maize is widely cultivated in Brazil, and nitrogen is a major nutrient for its yield. Azospirillum brasiliense bacteria help in plant nutrient supply; however, maize-Azospirillum symbiosis is not very efficient and requires selection of genotypes with a more efficient association. Multivariate indexes facilitate selection using a single value, and GGE-biplot analysis enables the visualization of the genotype-environment interaction from this value. The present study aimed to select progenies that effectively associate with the bacteria and study the efficiency of progeny selection using a multivariate index observed in the GGE-biplot method. The experiments were conducted in two cities in the state of Mato Grosso do Sul. In a simple $16 \times 16$ lattice, 256 genotypes were evaluated in the presence and absence of diazotrophic bacteria. PH, SL, SD, FI, HGM, SS, and GY were measured for the construction of a selection index. Genotypes exhibited significant genotypeenvironment interactions for all evaluated traits, allowing their use in the selection index. High-yield genotypes were not those with the highest selection index values. The traits GY, SD, HGM, SS, SL, and PH contributed the most to the construction of the index. The no-till system may have contributed to the weaker response of maize inoculated with Azospirillum brasiliense. Genotype 96 had the highest values of the characteristics used to calculate the GISI, along with the stability between environments.
\end{abstract}

Keywords: Zea mays L.. Nitrogen fixing bacteria. Maize breeding.

\section{INDICE MULTIVARIADO GGE-BIPLOT PARA SELECIONAR PROGÊNIES DE MILHO PARA EFICIENTE ASSOCIAÇÃO COM Azospirillum brasiliense}

RESUMO - O milho é amplamente cultivado no Brasil e Nitrogênio é seu principal nutriente para produção. Azospirillum brasiliense auxilia no suprimento desse nutriente às plantas, porém sua simbiose com milho não é muito eficiente. Índices multivariados permitem a seleção usando um único valor e a análise GGE-Biplot permite a visualização da interação genótipo $\mathrm{x}$ ambientes a partir desse valor. $\mathrm{O}$ estudo objetivou selecionar progênies de melhor associação com as bactérias e estudar a eficiência da seleção de progênies utilizando um índice multivariado observado no método GGE-Biplot. Os experimentos foram realizados em duas cidades do estado de Mato Grosso do Sul. Foram avaliados 256 genótipos, em látice simples 16x16, na presença e ausência das bactérias diazotróficas. Avaliou-se as características altura das plantas, comprimento da espiga, diâmetro do caule, intervalo de florescimento masculino e feminino, massa de cem grãos, sanidade e produtividade para construção do índice de seleção. Os genótipos apresentaram interação genótipos-ambientes significativa para todos os caracteres avaliados, permitindo o uso de todos no índice de seleção. Os genótipos apresentaram interação genótipos-ambientes significativa para todos os caracteres avaliados, permitindo o uso de todos no índice de seleção. Genótipos de alto rendimento não foram os mesmos com maior valor no índice. Os caracteres PROD, DC, MCG, NS, CE e AP foram os que mais contribuíram para a construção do índice. O sistema de plantio direto pode ter contribuído para a resposta mais fraca do milho à inoculação com Azospirillum brasiliense. O genótipo 96 apresentou valores mais altos das características usadas para calcular o GISI, representando maior estabilidade entre os ambientes.

Palavras-chave: Zea mays L. Bactérias fixadoras de nitrogênio. Melhoramento de milho.

\footnotetext{
${ }^{*}$ Corresponding author

${ }^{1}$ Received for publication in 04/17/2020; accepted in 05/27/2021.

Paper extracted from the masters dissertation of the first author.

${ }^{2}$ Department of Agricultural Science, Universidade Federal da Grande Dourados, Dourados, MS, Brazil; felipececcon92@gmail.com ORCID: 0000-0003-0477-9528, liviadavide@ufgd.edu.br - ORCID: - 0000-0003-1609-3750, manoelgoncalves@ufgd.edu.br - ORCID: 0000-0003-0055-1868, elainelourente@ufgd.edu.br - ORCID: 0000-0001-5658-7902.

${ }^{3}$ Department of Genetics and Plant Breeding, Embrapa Agroenergia, Brasilia, DF, Brazil; adriano.agro84@yahoo.com.br - ORCID: 0000$0003-4892-4723$.
} 


\section{INTRODUCTION}

Maize (Zea mays L.), a cereal grown in most parts of the world, has a high yield potential. An estimated 1.077 billion tons was harvested globally in 2018/2019, and the three major producers were the United States, China, and Brazil (USDA, 2019). These countries account for $66 \%$ of the world's corn production, where the yield is highly dependent on plant nutrition, mainly nitrogen, during cultivation (LONGHINI et al., 2017).

The gas fraction of the Earth's atmosphere consists of approximately $79 \%$ nitrogen; however, this nitrogen is in its elementary form $\left(\mathrm{N}_{2}\right)$ and cannot be assimilated by the plant. Nitrogen is mainly assimilated in the roots of plants via the addition of industrial fertilizers; but it is a costly process that consumes non-renewable fossil fuels. In soybean, the main crop cultivated in Brazil, nitrogen is supplied by the bacterial genus Bradyrhizobium, which in their symbiosis with the plant provides nutrients inside the root cells. In corn, this symbiosis occurs with the bacterial genus Azospirillum; however, it does not infect or fix nitrogen inside the cells, decreasing the performance efficiency of diazotrophic organisms in corn than in soybean (HUNGRIA et al., 2010).

Research on Azospirillum in Z. mays L. has been important since the 1980s that began with studies by Albrecht et al. (1981). Initially, bacteria were inoculated in sterilized maize seedlings in an isolated greenhouse and this interaction was evaluated in field experiments with non-inoculated Z. mays L. Although the authors concluded to not finding benefits to maize plants, they observed a significant effect in the nitrogenase enzyme and nitrogen content, which encouraged subsequent research in studying this symbiosis.

The genus Azospirillum is characterized by free-living bacteria that inhabit both the rhizosphere and the interior of the Maize root. This mechanism of association without nodulation makes it inefficient because the plant needs to absorb the nutrients that are fixed in the soil solution. However, performance among hybrids inoculated with Azospirillum differ, such that certain genotypes may exhibit higher yield depending on the inoculation, while others may vegetate for longer, resulting in a lower yield (QUADROS et al., 2014).

The importance of selecting genotypes to efficiently associate with nitrogen-fixing bacteria may contribute to a decreased dependency on mineral fertilizers. Nitrogen added via urea, for example, is subjected to ammonia reduction and consequent loss by volatilization. Inoculation with Azospirillum bacteria, besides aiding in the supply of organic nitrogen, alters the composition of the rhizosphere microbiota, which also affects aspects such as plant resistance to pathogenesis (HAICHAR et al., 2008; VIMAL et al., 2017). In this context, the selection of genotypes for efficient interaction with Azospirillum is important to profit from inoculation, while playing an important role in sustainability.

The selection of several traits observed in individuals tested from many sites can be complex because of the collection of large amounts of experimental information (ARAUJO; VIVAS, 2018). The multivariate statistic is a tool suggested in plant breeding to transform the original traits into a new response trait, forming an index of genotype selection (YAN; FRÉGEAU-REID, 2018).

GGE-biplot analysis is another tool in plant breeding for genotype evaluation in different environments. It allows the unfolding of genotype $(\mathrm{G})$, environment (E), and genotype-environment interaction (GE) effects observed in two-way data and constructs graphs that allow the visualization of genotype adaptability and stability (YAN et al., 2000). However, Yan et al. (2007) observed that biplot analysis is simply a visually descriptive statistical tool, and Yang et al. (2009) concluded that inferences using it should proceed with caution.

In this context, the objective of this study was to select progenies for efficient interaction with Azospirillum brasiliense bacteria and study the efficiency of genotype selection by applying a multivariated index using the GGE-biplot method.

\section{MATERIAL AND METHODS}

The experiments were conducted in two Mato Grosso do Sul state cities; the coordinates of Dourados is $22^{\circ} 11^{\prime} 55^{\prime \prime} \mathrm{S}$ and $54^{\circ} 56^{\prime} 07^{\prime \prime} \mathrm{W}$, with an altitude of $452 \mathrm{~m}$, and for Caarapó, the coordinates are $22^{\circ} 33^{\prime} 7.3^{\prime \prime} \mathrm{S}$ and $54^{\circ} 50^{\prime} 1.3^{\prime \prime} \mathrm{W}$, with an altitude of $411 \mathrm{~m}$. Experimental seeds were sown on March 9 in Dourados, and on March 21 in Caarapó. Prior to sowing at Dourados, the soil was prepared with a 30 $\mathrm{cm}$ stem plow and a harrow. The sowing row was fertilized using a sowing machine to regulate the distribution of $200 \mathrm{~kg} \mathrm{ha}^{-1}$ of $8-20-18$ (N-P-K) fertilizer $(25 \mathrm{~kg}$ of $\mathrm{N})$.

In Caarapó, maize was grown under no-tillage after soybean cultivation, and the property was in its fifth year without soil tillage. The sowing row was fertilized with a combination of $150 \mathrm{~kg} \mathrm{ha}^{-1}$ of the formula 11-31-17 (N-P-K) and $90 \mathrm{~kg} \mathrm{ha}^{-1}$ of $\mathrm{KCl}$ $(22 \mathrm{~kg}$ of $\mathrm{N})$. The two sites were cover fertilized 30 days after the emergence of corn plants (DAE) by adding $15 \mathrm{~kg} \mathrm{ha}^{-1}$ of urea $(45 \% \mathrm{~N})$ to the sides of the sowing line ( $7 \mathrm{~kg}$ of $\mathrm{N})$.

In total, 32 and $29 \mathrm{~kg}$ of $\mathrm{N}$ were available for the experiments in Dourados and Caarapó, respectively, which according to an average of 25 tests presented by Raij (1981), yielded up to $4,500 \mathrm{~kg} \mathrm{ha}^{-1}$ of $\mathrm{N}$. This sub-dose of nutrient was imposed due to the fact that the metabolic activity of nitrogenase enzyme decreases in the presence of ammonia, causing the bacteria to accumulate 
energetic compounds that deter the breaking of $\mathrm{N}_{2}$ molecules, causing nitrogen fixation (SUN et al., 2002).

In Dourados, at 30 DAE, a combination of $28 \mathrm{~g} \mathrm{ha}^{-1}$ of Tiametoxan and $21 \mathrm{~g} \mathrm{ha}^{-1}$ of lambdacyhalothrin were sprayed. At 50 DAE, $100 \mathrm{~g} \mathrm{ha}^{-1}$ of imidacloprid was applied, with $15 \mathrm{~g} \mathrm{ha}^{-1}$ of Teflubenzurom and $1 \mathrm{~kg} \mathrm{ha}^{-1}$ of atrazine. In Caarapó at $30 \mathrm{DAE}, 86 \mathrm{~g} \mathrm{ha}^{-1}$ methomyl were applied with $45 \mathrm{~g} \mathrm{ha}^{-1}$ of bifenthrin, $62 \mathrm{~g} \mathrm{ha}^{-1}$ azoxystrobin and
$62 \mathrm{~g} \mathrm{ha}^{-1}$ flutriafol, and at 57 DAE, $20 \mathrm{~g} \mathrm{ha}^{-1}$ of chlorantraniliprole with $2 \mathrm{~kg} \mathrm{ha}^{-1}$ of atrazine were added. At 40 and $60 \mathrm{DAE}, 1 \mathrm{~L} \mathrm{ha}^{-1}$ of a liquid fertilizer (12 g organic carbon, $50 \mathrm{~g} \mathrm{~N}, 12 \mathrm{~g} \mathrm{P}_{2} \mathrm{O}_{5}$, $12 \mathrm{~g} \mathrm{Ca}, 12 \mathrm{~g} \mathrm{Mg}, 23 \mathrm{~g} \mathrm{~S}, 4 \mathrm{~g}$ Bo, $37 \mathrm{~g} \mathrm{Mn}, 1 \mathrm{~g} \mathrm{Mo}$, $12 \mathrm{~g}$ zinc, and $1 \mathrm{~g} \mathrm{Ni}$ ) was added. The climatological conditions during the experiments were assessed using the EMBRAPA automatic meteorological stations (Figures 1 and 2).

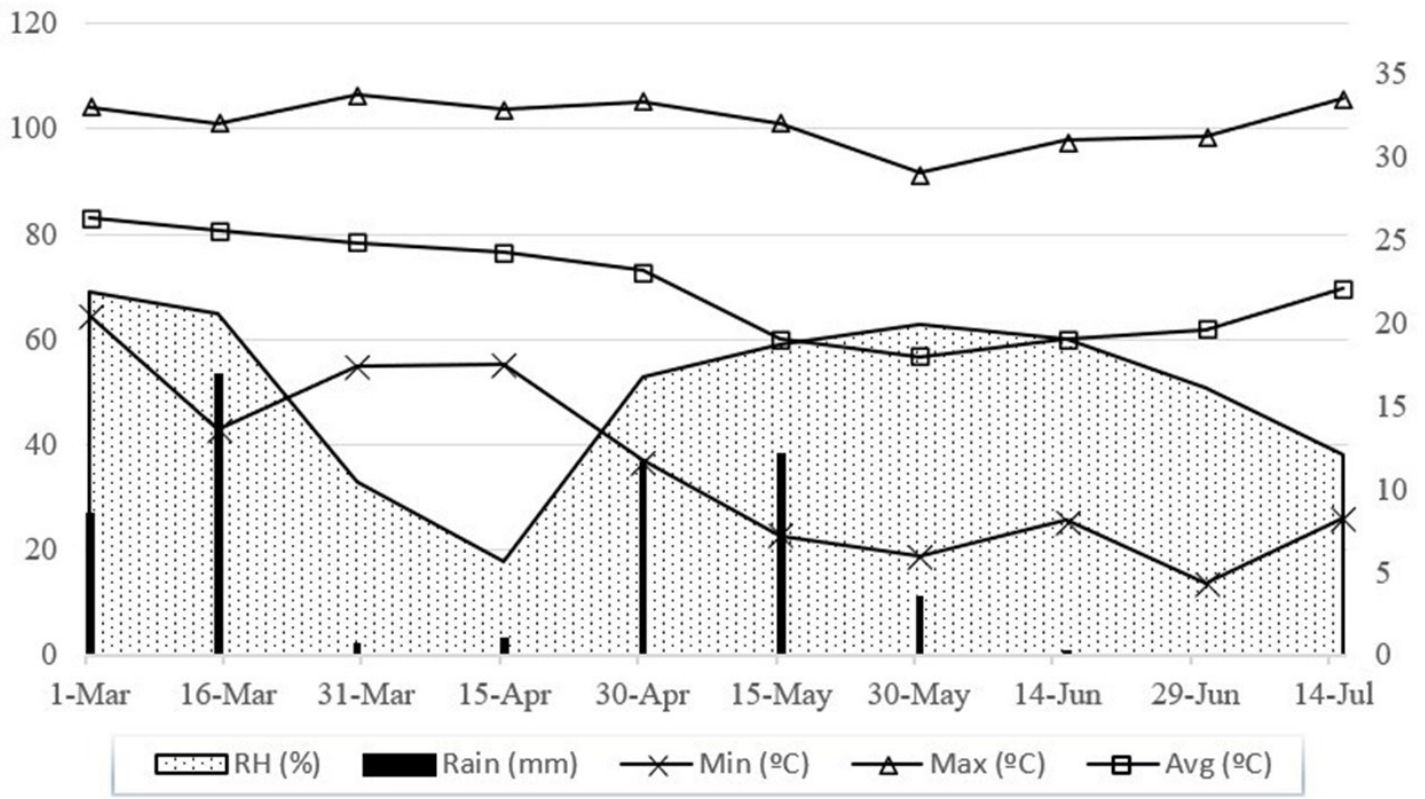

Figure 1. Data on biweekly relative humidity $(\mathrm{RH})$, rainfall (accumulation in mm), minimum temperature, maximum temperature, and average temperature $\left(\right.$ in ${ }^{\circ} \mathrm{C}$ ) of the Dourados region from March to July 2018

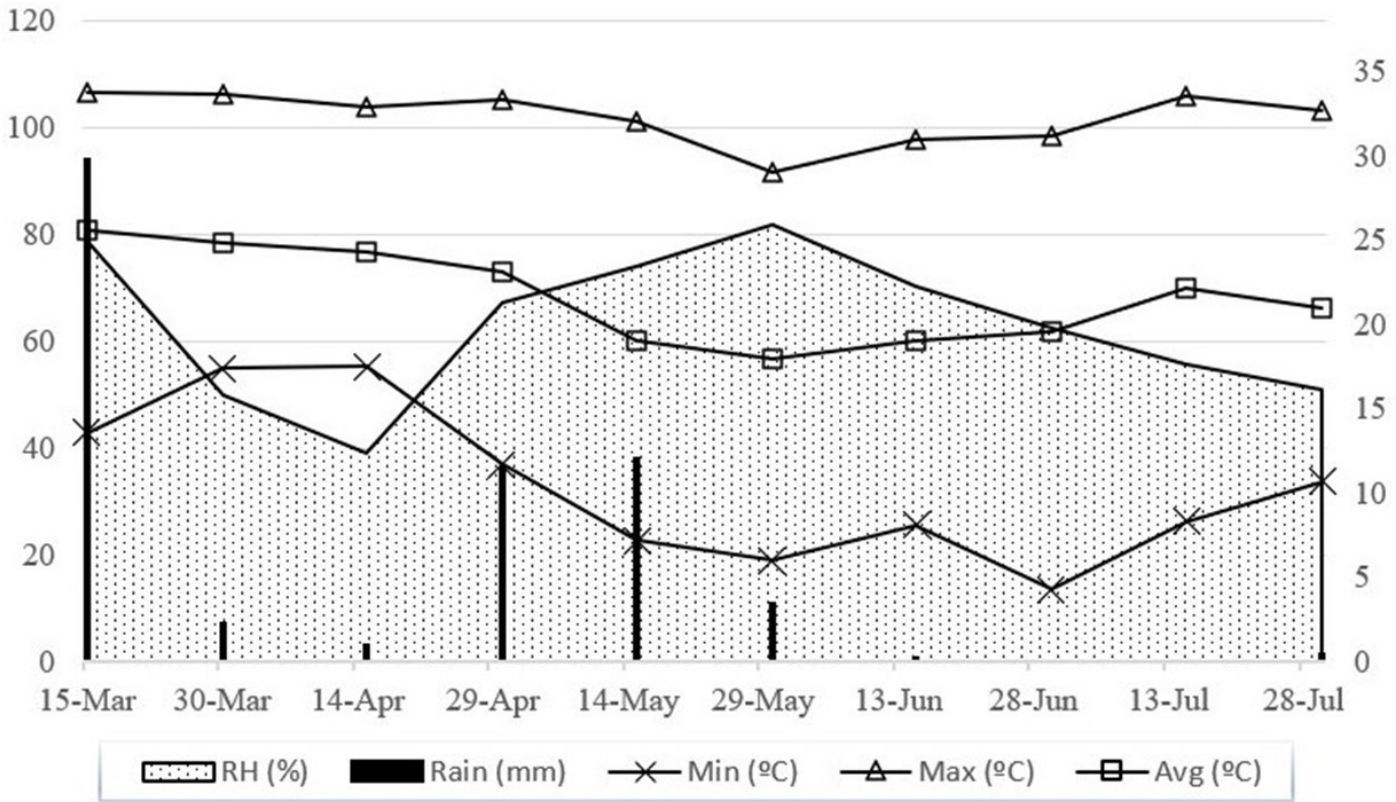

Figure 2. Data on biweekly relative humidity $(\mathrm{RH})$, rainfall (accumulation in $\mathrm{mm}$ ), minimum temperature, maximum temperature, and average temperature $\left(\right.$ in ${ }^{\circ} \mathrm{C}$ ) of the Caarapó region from March to July 2018. 
A total of 256 genotypes were evaluated; 250 half-sib progenies and five progenitors and one cultivar adapted to the region of Mato Grosso do Sul were added to the design as a check genotype. To obtain the progenies, these five cultivars (three open pollinated varieties and two simple hybrids) were sown in an isolated field to avoid contamination by exogenous pollen, during the 2017/2018 harvest season. In the present study, fifty ears of each cultivar were selected, which were threshed and treated prior to their evaluation.

In this evaluation, a simple $16 \times 16$ lattice was used as the experimental design owing to the high number of genotypes. Each experimental unit consisted of a $3.30 \mathrm{~m}$ row, spaced by $0.33 \mathrm{~m}$ between plants and $0.45 \mathrm{~m}$ between rows. Two seeds were sown per pit, and at $21 \mathrm{DAE}$, the pits with two germinated seeds were thinned leaving one plant per pit, resulting in a stand of 10 plants per plot that represented a population stand of approximately 74000 plants ha ${ }^{-1}$.

The genotypes were submitted to the presence and absence of Azospirillum brasiliense bacterial species; the bacteria was inoculated $4 \mathrm{~h}$ prior to sowing at $150 \mathrm{~mL} \mathrm{ha}^{-1}$ dose recommended by the manufacturer of the product (minimum assurance of concentration: $2 \times 10^{8}$ viable cells $\mathrm{mL}^{-1}$ ).

In order to verify genotype-environment interaction, the following traits were evaluated: i) plant height $(\mathrm{PH})$ : average of five central plants in the plot from the plant neck to the tassel insertion (measured in m); (ii) spike length (SL): average of five random ears from the base to tip of the ear (measured in $\mathrm{cm}$ ); iii) stem diameter (SD): average of five central plants in the plot evaluated (in $\mathrm{cm}$ ) and with a pachymeter, at one meter height from the ground in the middle of the internode; iv) flowering interval (FI): difference between male and female flowering days of all plants in the plot; v) sanity score (SS): visually attributed value during flowering ranging from 1 to 5 , where plots $1,2,3,4$, and 5 are attributed to $80-100 \%, 60-80 \%, 40-60 \%, 20-40 \%$, and $0-20 \%$ of leaves with symptoms of pest or disease attack, respectively; vi) hundred grain mass (HGM): mass of one hundred grains of each plot (in $\mathrm{g}$ ), corrected to $13 \%$ moisture in the grain; and (vii) grain yield (GY): obtained by weighing the grain of all the plants of the plot to $13 \%$ humidity and extrapolated by rule of three to $\mathrm{kg} \mathrm{ha}^{-1}$.

The Shapiro-Wilk test was initially performed to verify the homogeneity of the residual variance. Thereafter, analysis of variance (ANOVA) was performed that considered the effects of genotype, cities, and Azospirillum brasiliense, with the objective of determining possible significance in the interaction of maize genotypes with the bacteria.

Araújo et al. (2010) evaluated the interaction between genotypes, environments, and years through biplot analysis, which allowed the study of identifying the source of variation that contributed the most to the significant interaction. Thus, in the present study, the triple interaction was interpreted using the GGE-biplot analysis because only the eigenvectors of the genotype and the $\mathrm{G} \times \mathrm{E}$ interaction were used.

Owing to the large amount of experimental information obtained, a new response trait was calculated as a genotype selection index. The index comprises of the Mahalanobis generalized distance between the evaluated genotypes and an ideal genotype (ideotype). According to Khakwani et al. (2018), a maize ideotype should grow under adverse conditions to ensure food security. The ideal numbers were determined by seeking the highest value of the traits among all plots, with the exception of FI, which had the lowest number that indicated the shortest interval between pollen shed and silk emergence. The numbers used to calculate distances are listed in Table 1. The Mahalanobis generalized distances are referred to in the text as the GenotypeIdeotype Selection Index (GISI).

Table 1. Highest value observed on all plots (HVOP) and Ideal value assigned for the trait (IVAT) for FI (flowering interval), SD (stem diameter), PH (plant height), SL (spike length), HGM (mass of one hundred grains), SS (sanity score) and GY (grain yield) evaluated in 256 maize genotypes at four evaluation sites in 2018.

\begin{tabular}{ccc}
\hline Trait & HVOP & IVAT \\
\hline FI & 9.0 & 0.0 \\
SD & 2.1 & 3.0 \\
PH & 2.1 & 2.4 \\
SL & 16.0 & 18.0 \\
HGM & 369.7 & 400.0 \\
SS & 2.0 & 5.0 \\
GY & 5991.1 & 7000.0 \\
\hline
\end{tabular}


The distances were calculated using the multivariate analysis to obtain the variance and covariance matrix of the original traits. The model expressed in Equation 1, proposed by Ferreira (2018), was used to obtain this matrix. In the model, $Y_{i j}$ refers to the observations of the $i^{\text {th }}$ genotype in the $j^{\text {th }}$ environment, $\mu$ is the average vector of the evaluated traits, $\alpha_{i}$ is the genotype vector of random effects, $\beta_{\mathrm{j}}$ is the vector of fixed effects of the environments, $\delta_{\mathrm{ij}}$ is the vector of effects of the interaction of genotypes and environments, and $\varepsilon_{\mathrm{ij}}$ is the vector of corresponding residual effects.

$$
Y_{i j}=\mu+\alpha_{i}+\beta_{j}+\delta_{i j}+\varepsilon_{i j}
$$

The multivariate analysis of variance (MANOVA) model notably differs from the univariate analysis model. In the latter, the effects of bacterial treatments and the two cities were analyzed separately. In the MANOVA model, the 256 genotypes were analyzed at four sites: Dourados inoculated (DI), Dourados not-inoculated (DN), Caarapó inoculated (CI), and Caarapó not-inoculated $(\mathrm{CN})$.

The Shapiro-Wilk test performed for the residual effects checked the normal multivariate distribution of the seven traits. After verification of this assumption, the $7 \times 7$ sum of squares and residual product matrix had each element divided by the residue degree of freedom, generating the matrix $\mathrm{S}$ (residual variances and covariance).

The calculation of the index was performed by matrix algebra using Equation 2, proposed by Oliveira et al. (2014).

$$
D_{2}=\operatorname{diag}\left(\mathrm{IS}^{-1} \mathrm{I}^{\prime}\right)
$$

where $D_{2}$ is the vector $2048 \times 1$ of the plot distances from the ideotype, $\mathrm{I}$ is the $2048 \times 7$ matrix of the differences between each of the traits evaluated in the plots and its ideal value, $\mathrm{S}^{-1}$ is the transpose of the variances and covariates of matrix $7 \times 7$ obtained by multivariate analysis of the seven traits, and I' is the inverse $7 \times 2048$ of the matrix of differences between traits and ideal values.

It is observed that by solving the term $\mathrm{IS}^{-1} \mathrm{I}^{\prime}$, a matrix of order $2048 \times 2048$ is obtained; however, the term "diag" causes the result of the complete expression to only be the elements of the main diagonal of the matrix, which corresponds to the distances between each plot and the ideotype. As the distance interpreted is the opposite of yield, that is, the smaller the distance, the greater the genotype performance, the values in each plot decreased from 2000, which is the thousand above the most distant plot, characterizing the GISI.

After obtaining the GISI, the Shapiro-Wilk tests were performed to assess the normal distribution of residues and the analysis of variance of this new trait to evaluate the GxE interaction, and use its averages to evaluate the genotype adaptability and stability. The GGE biplot chart was constructed based on the GISI values assigned to each genotype in each environment. The model represented by Equation 3, recommended by Yan (2001), was used to construct the points and vectors in the graph.

$$
\overline{\mathrm{Y}}_{i j}-\mu_{j}-\beta_{j}=\lambda_{1} \xi \mathrm{i}_{1} \eta_{1} \mathrm{j}+\lambda_{2} \xi \mathrm{i}_{2} \eta_{2} \mathrm{j}+\varepsilon_{i j}
$$

where $\bar{Y}_{i j}$ is the average GISI value of the $i^{\text {th }}$ genotype in the $j^{\text {th }}$ environment, $\mu_{j}$ is the GISI average in the $\mathrm{j}^{\text {th }}$ environment, $\beta_{\mathrm{j}}$ is the main effect of the environment $\mathrm{j}, \lambda_{1}$ and $\lambda_{2}$ are the major eigenvalues of the principal components (PC) 1 and 2 of the PCA, which multiply $\xi$ and $\eta$ eigenvectors of each component concerning the genotype and the environment, respectively.

To analyze the traits used in the construction of the multivariate index, the genotype by trait biplot (GT-biplot) analysis was performed as proposed by Wickham (2010) and used by Araujo and Viva (2018) and Oliveira et al. (2018). The analysis of variance, matrix calculations, and construction of the GGE-biplot and GT-biplot graphs were performed using R (R CORE TEAM, 2018) computational software.

\section{RESULTS AND DISCUSSION}

The Shapiro-Wilk test confirmed the homogeneity of the residual variance of the experimental data; and the ANOVA can be used to assess the cause of data variance. In the ANOVA, the effects of genotypes, the presence of nitrogenfixing bacteria, and environmental conditions throughout the trial were significant with $1 \%$ probability, indicating that the differences observed in traits were due to the effect of genotypes, bacteria, or environmental conditions. In addition, according to the ANOVA, the interaction between the three sources of variation was significant, with a probability of $1 \%$. As explained before, to fit the data into the multivariate analysis model (Equation 1), the presence and absence of the bacteria in Dourados and Caarapó were considered as evaluation sites, which facilitates the simultaneous assessment of the effect of the bacteria by considering data from two cities.

The effect of bacteria is mostly discussed in terms of genotype grain yield. Therefore, the genetic structure of different genotypes must be considered before assessing this effect. The yielding capacity of open-pollinated varieties, single-cross hybrids, and half-sib progenies should be taken into consideration. The first 250 are half-sib progenies of commercial cultivars (genotypes 251, 252, 253, 254, 
and 255). Cultivars 251, 252, and 253 are openpollinated varieties and cultivars 254 and 255 are single-cross hybrids, similar to the adapted cultivar checker (genotype 256).

As seen in Table 2, in this study, the GY variation ranged from 1,498 to $4,420 \mathrm{~kg} \mathrm{ha}^{-1}$. Genotype 256 exhibited the highest GY average among the four evaluation sites, followed by the half -sib progenies of genotype 255. Genotype 255 independently had an average of $2,820 \mathrm{~kg} \mathrm{ha}^{-1}$, while its 50 progenies further yielded $819 \mathrm{~kg} \mathrm{ha}^{-1}$ $\left(3,639 \mathrm{~kg} \mathrm{ha}^{-1}\right)$, considering the four sites. Genotype 254 had an average GY of 2,325 kg ha $\mathrm{kg}^{-1}$, and 50 progenies had an average yield of $2,360 \mathrm{~kg} \mathrm{ha}^{-1}$. Genotype 253 and its progenies exhibited an average GY of 3,195 kg ha ${ }^{-1}$ and $2,557 \mathrm{~kg} \mathrm{ha}^{-1}$, respectively. Genotype 252 showed 2,666 kg ha-1, whereas the progenies showed $2,245 \mathrm{~kg} \mathrm{ha}^{-1}$ average GY. Genotype 251 had an average of $2,575 \mathrm{~kg} \mathrm{ha}^{-1}$, whereas the progenies averaged at $2,560 \mathrm{~kg} \mathrm{ha}^{-1}$.

Table 2. Grain yield (GY) and Genotype-Ideotype Selection Index (GISI) rank of ten genotypes with the highest and lowest GY average of Dourados inoculated (DI), Dourados not inoculated (DN), Caarapó inoculated (CI) and Caarapó not inoculated $(\mathrm{CN})$ evaluation sites in 2018.

\begin{tabular}{cccc}
\hline Rank & Genotype & GY* & GISI* \\
\hline $1^{\mathrm{o}}$ & 256 & $4420 \mathrm{a}$ & $980 \mathrm{c}$ \\
$2^{\mathrm{o}}$ & 241 & $4284 \mathrm{a}$ & $1013 \mathrm{~b}$ \\
$3^{\mathrm{o}}$ & 246 & $4052 \mathrm{~b}$ & $1012 \mathrm{~b}$ \\
$4^{\mathrm{o}}$ & 234 & $4003 \mathrm{~b}$ & $1004 \mathrm{~b}$ \\
$5^{\mathrm{o}}$ & 244 & $3971 \mathrm{~b}$ & $1027 \mathrm{a}$ \\
$6^{\mathrm{o}}$ & 217 & $3962 \mathrm{~b}$ & $1005 \mathrm{~b}$ \\
$7^{\mathrm{o}}$ & 215 & $3959 \mathrm{~b}$ & $957 \mathrm{~d}$ \\
$8^{\mathrm{o}}$ & 211 & $3921 \mathrm{~b}$ & $975 \mathrm{c}$ \\
$9^{\mathrm{o}}$ & 224 & $3895 \mathrm{c}$ & $1035 \mathrm{a}$ \\
$10^{\circ}$ & 206 & $3881 \mathrm{c}$ & $1003 \mathrm{~b}$ \\
$247^{\circ}$ & 154 & $1939 \mathrm{r}$ & $672 \mathrm{i}$ \\
$248^{\circ}$ & 66 & $1932 \mathrm{r}$ & $831 \mathrm{f}$ \\
$249^{\circ}$ & 59 & $1913 \mathrm{r}$ & $960 \mathrm{~d}$ \\
$250^{\circ}$ & 176 & $1854 \mathrm{~s}$ & $726 \mathrm{~h}$ \\
$251^{\circ}$ & 85 & $1814 \mathrm{~s}$ & $882 \mathrm{e}$ \\
$252^{\circ}$ & 96 & $1782 \mathrm{t}$ & $690 \mathrm{i}$ \\
$253^{\circ}$ & 98 & $1745 \mathrm{t}$ & $703 \mathrm{i}$ \\
$254^{\circ}$ & 88 & $1584 \mathrm{u}$ & $827 \mathrm{f}$ \\
$255^{\circ}$ & 90 & $1500 \mathrm{u}$ & $693 \mathrm{i}$ \\
$256^{\circ}$ & 92 & $1498 \mathrm{u}$ & $673 \mathrm{i}$ \\
\hline
\end{tabular}

*Average of four evaluation sites; the same letter on the column does not differ statistically from Skott-Knott 5\% probability test.

Among the parentals, the progenies of singlecross hybrids had a higher yield than the female progenitors, while on average, the progenies of the three open-pollinated varieties presented lower yielding capacity. These three genotypes do not completely transfer their genes to the offspring; they are randomly formed with each generation of crosspollination. Hybrids were obtained from the crossing between divergent and complementary strains from different heterotic groups; it combines a wide variety of characters from different parents in a certain individual, resulting in favorable genes that appear at a high frequency in the dominant or heterozygous condition (MELO et al., 2019). During crosspollination between these five parents, progenies from hybrid parents already contained this wide variety of alleles. Therefore, when they receive pollen from other individuals, they tend to receive alleles that do not exist in their mother plant, which may explain the greater phenotypic expression of productivity.

Although the evaluation was based on the phenotype, the alleles were selected. In this case, half-sibs from the hybrids are of interest to the breeding program because of their high yielding potential. However, this does not diminish the importance of selecting progenies from the openpollinated varieties, because of the fact that their genetics are randomly formed; favorable alleles may exist in these progenies in the dominant form (OKOYE et al., 2018), but may serve as a genetic source of resistance and adaptability of genotypes that are to be selected in other stages of the program.

Azospirillum brasiliense bacteria can affect the cycle of the plant (CURÁ et al., 2017), which implies the need to select genotypes that increase yield capacity after inoculation. The interaction between the 250 progenies and the bacteria was also significant at $1 \%$ probability (ANOVA), which allowed the study of progenies that increased GY 
due to inoculation. However, the change in phenotypic expression resulting from inoculation is not hereditary (VIDOTTI et al., 2019), resulting in difficulties in selecting genotypes. Therefore, the generalized distance between genotypes and the ideotype (GISI) has been used to represent all traits measured in plants, including grain yield.

To assess the significance of each trait on the multivariate index and to increase confidence in progeny selection, genotype-by-trait biplot (GTBiplot) analysis was performed (Figure 3). The principal components used in the construction of the figure represent $87.98 \%$ of the data variation. According to Yang et al. (2009), the graph should represent at least $60 \%$ of the data variation, allowing a straightforward interpretation of the contribution of the traits in the index construction.

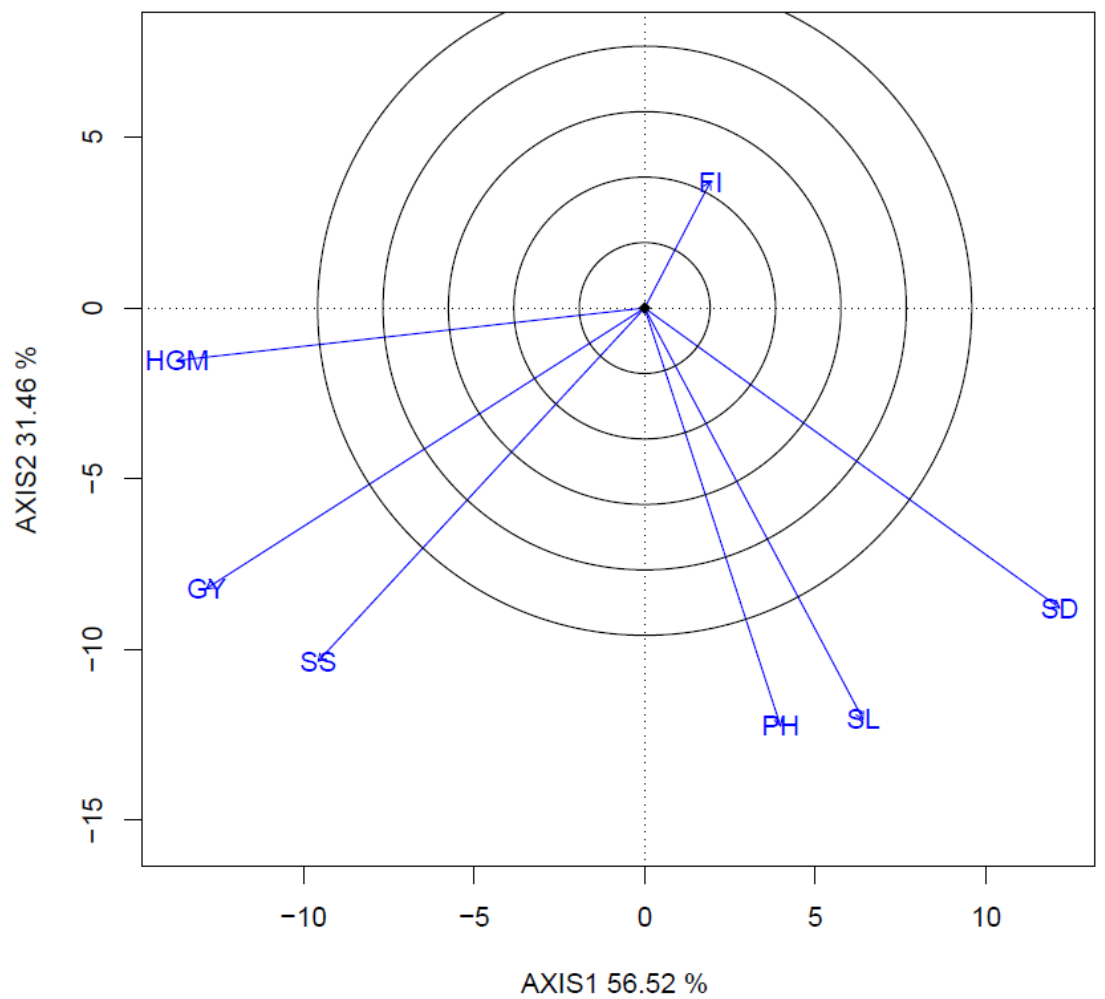

Figure 3. GT-biplot representing the relationship between PH: plant height, SL: spike length, SD: stem diameter, FI: flowering interval, HGM: mass of one hundred grains, SS: sanity score and GY: grain yield evaluated in 256 maize genotypes under the presence and absence of Azospirillum brasiliense bacteria treatments at four evaluation sites in 2018.

For the relationship between the traits (Figure 3 ), the cosines of the angles between the vectors of each trait were related to the correlation coefficients between them. Thus, one can observe the existence of a positive correlation between GY and HGM, SS, $\mathrm{PH}$, and SL, because the cosine of the angle between them is positive, that is, the angle is less than $90^{\circ}$ (YAN; HOLLAND, 2010). However, FI was negatively correlated with all the traits. This result is consistent, since a shorter interval between male and female flowering will allow gains in GY. This occurs because of the greater amount of pollen during the emission phase of the style-stigmas, increasing the number of fertilized eggs.

According to the length of vectors, the traits GY, SD, HGM, SS, SL, and PH contributed the most to the construction of the index. Evidently, there was a positive genetic correlation between GY and all traits, except SD and FI; the index facilitates simultaneous selection of progenies that considers the characters GY, PH, SL, SS, and HGM.

In this study, while observing the DI and DN environment vectors, inoculated Azospirillum brasiliense bacteria effectively altered the Dourados environmental conditions (Figure 4). However, when Caarapó's vector was observed, the change seen in the figure was not as effective as in Dourados. Thus, an evaluation of the site's representativeness, as well as their genotype discrimination capacity, is of significance.

The DI vector was distant from the $\mathrm{DN}$ vector, whereas the $\mathrm{CI}$ and $\mathrm{CN}$ vectors remained close. According to Yan and Tinker (2006), when two environment vectors are approximate, they have a positive correlation. The cosine of the angle between the DI and DN vectors represents the correlation between these environments, indicating their positive correlation, which is also observed 
between the $\mathrm{CI}$ and $\mathrm{CN}$ vectors. However, there is a negative correlation between DI, DN and CI, CN. Thus, the information obtained in the DI and DN environments differs from that obtained in the CI and $\mathrm{CN}$ environments. In general, it was also observed that the environments presented a similar capacity for discriminating genotypes. This is observed by the vector length of the environments; that is, the longer the vector, the greater the discrimination capacity of the genotypes.

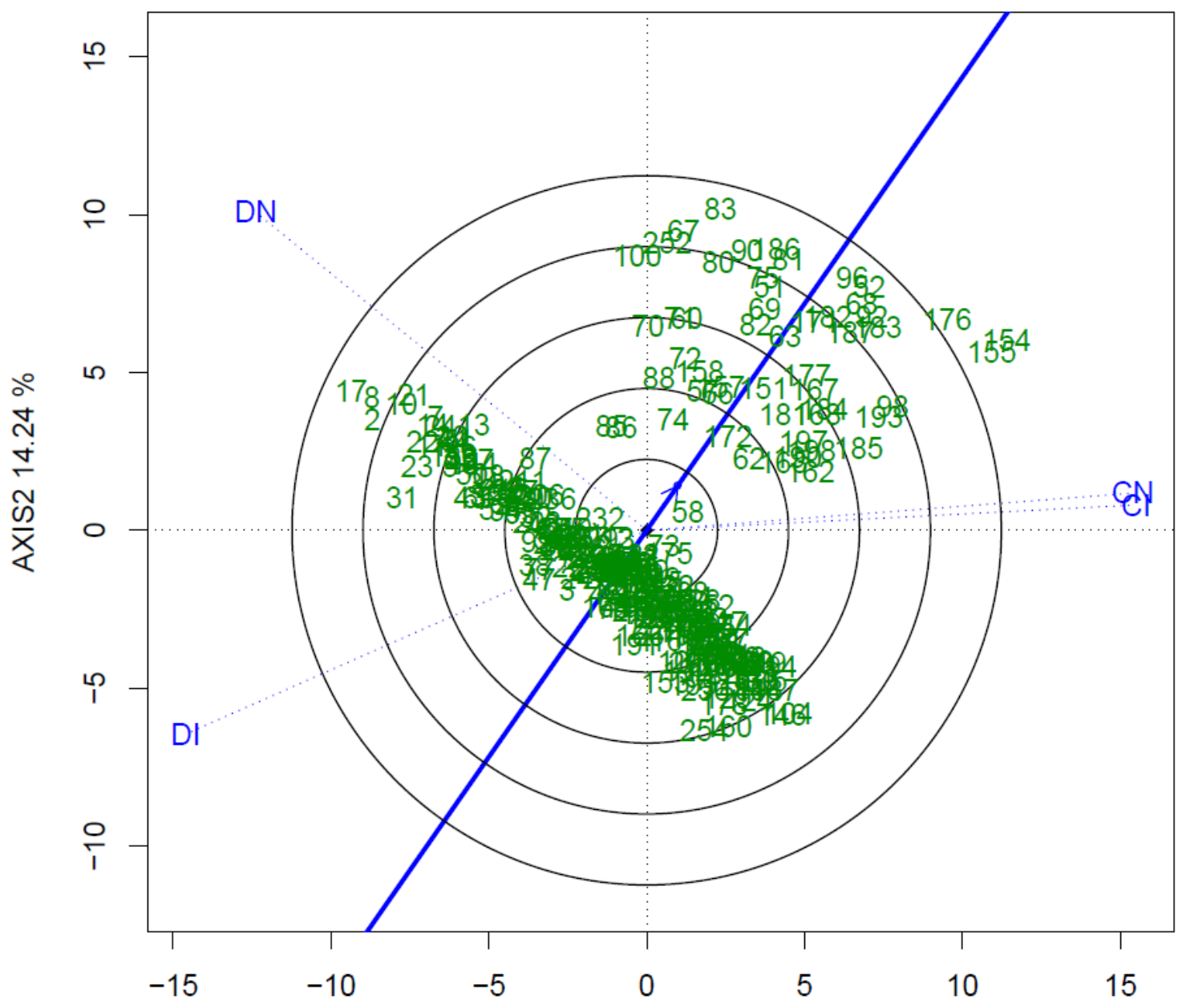

AXIS1 $82.73 \%$

Figure 4. GGE biplot for environments discriminativeness and representativeness from the genotype-ideotype selection index (GISI) of 256 genotypes evaluated at Dourados inoculated (DI), Dourados not inoculated (DN), Caarapó inoculated (CI) and Caarapó not inoculated (CN) sites in 2018.

The solid blue line that traces the graph is the Middle Environment Axis (MEA) and represents the overall environment average. The smaller the angle between the environment and the MEA, the greater the representativeness of the environment. Similarly, the longer the vector, the greater the genotype discrimination capacity (YAN; TINKER, 2006). It can be observed that $\mathrm{CN}$ and $\mathrm{CI}$ have a lower angle than DI and DN in comparison to MEA; therefore, $\mathrm{CI}$ and $\mathrm{CN}$ are more representative with similar ability to discriminate genotypes because of their close association.

In the second half of april, water availability in the experiments was unfavorable, considering both relative humidity and rainfall accumulation (Figures 1 and 2). During this period, maize plants in Dourados were at $30 \mathrm{DAE}$ with 5 to 7 expanded leaves, which is an important phenological stage to define the crop production components (FANCELLI; DOURADO NETO, 2000; BERGAMASCHI et al., 2006).

Due to the 12-day difference between the experimental sowing dates, genotypes in Caarapó reached 5 to 7 expanded leaves approximately on April 27, when rainfall and relative humidity were favorable for the plants (Figure 2). Since the inoculation of Azospirillum bacteria increases water tolerance in maize due to a greater control of the 
osmotic pressure (CURÁ et al., 2017), inoculation in Dourados may have aided genotypes at this important phenological stage. In this context, genotypes developed better with bacterial inoculation than without the bacteria in Dourados. This apparently did not occur in Caarapó because of the availability of water available during the same phenological stage, which may indicate that inoculation in Caarapó did not interfere much with the development of the genotypes.

Azospirillum inoculation functions beyond root nitrogen fixation; the bacteria synthesize plant hormones that can interfere with plant development and protect their roots against pathogenic organisms in the rhizosphere microbiome (SOUZA et al., 2017). The availability of Azospirillum in the Dourados environment may have increased genotype responses from the inoculation effects, since soil tillage causes adverse effects on soil biota (BENDER; WAGG; HEIJDEN, 2016) by decreasing competition with native individuals. These effects may have contributed to the increase in the angle between the DI and DN vectors. In Caarapó city, the native microbial biomass was unaffected due to notillage, which may have contributed to the weaker response of maize inoculated with Azospirillum brasiliense.

The MEA is shown in Figure 5, which evaluates the environmental adaptability of genotypes according to the selection index. The axis perpendicular to the MEA, the green y-axis, represents genotype stability, resulting in environmental differences (YAN, 2001). The adaptability of the cultivars is measured by their distance to the MEA; that is, the larger the length of the projection of a cultivar, the less it is adapted to the environment. Thus, progeny 17 was the least adapted, while progenies 63 and 172 were the most adapted. The green $y$-axis in Figure 5 indicates a significant effect of the genotype $\times$ environment interaction and less stability, as it also separates the genotypes that are below and above the GISI average (YAN; TINKER, 2006; YAN et al. 2007).

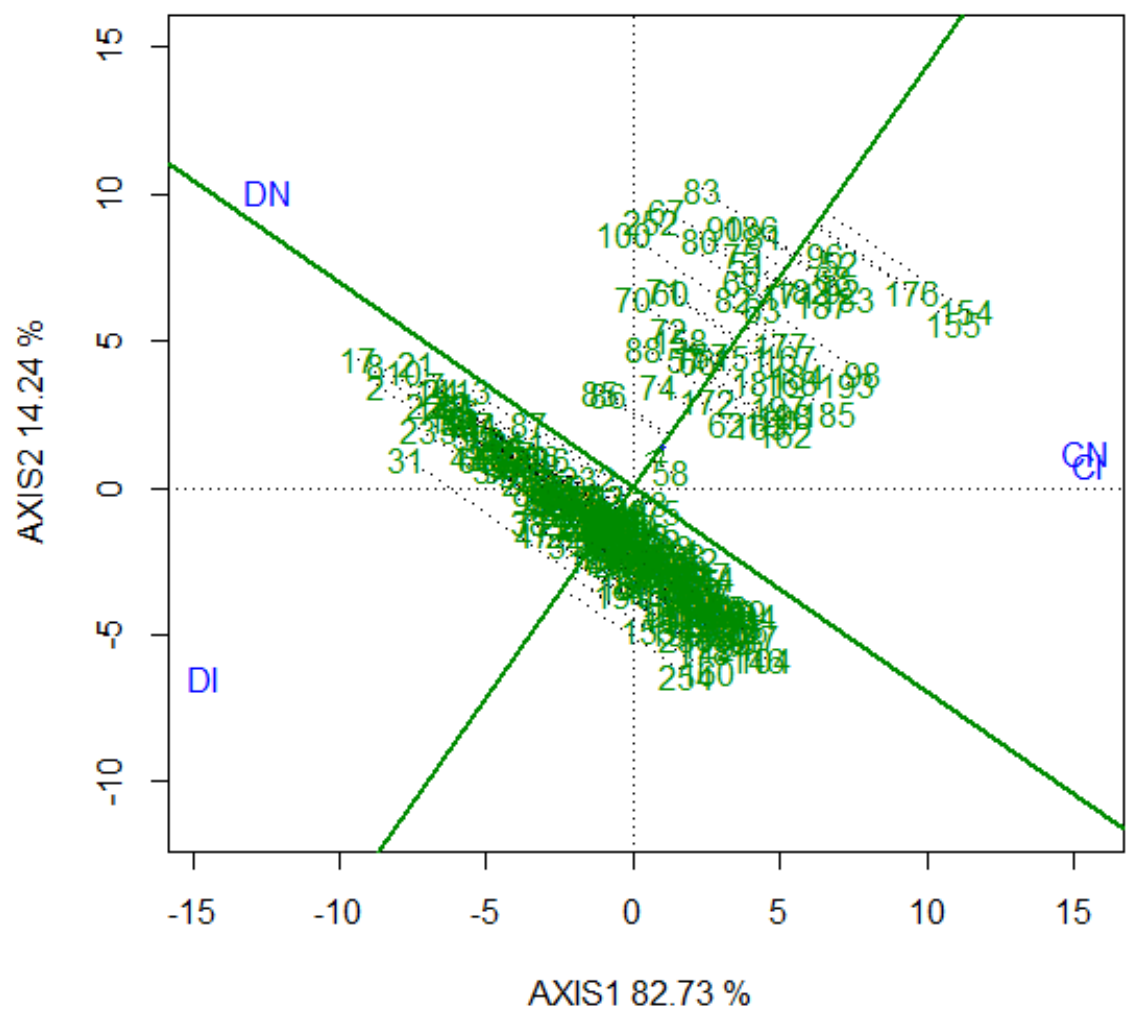

Figure 5. GGE biplot representing the genotypes adaptability and stability of the genotype-ideotype selection index (GISI) from 256 genotypes evaluated at Dourados inoculated (DI), Dourados not inoculated (DN), Caarapó inoculated (CI) and Caarapó not inoculated (CN) sites in 2018.

Therefore, the genotypes 154, 155, 176, 92, and 96 had the best performance index. However, progeny 154 was associated with low stability, that is, it contributed the most to GE interaction. This result corroborates with the work of Sharma et al. (2009) and Savemore, Manjeru and Ncube (2017), who also observed that the highest yielding genotypes are not always the most stable in all 
environments. Unstable genotypes are undesired in a breeding program, as they intend to increase the frequency of crop failures when grown in commercial fields. Instability has a negative effect on farmers' income and may contribute to food and nutritional insecurity both domestically and nationally.

The visualization of the "which won where" graph (Figure 6), enables the identification of promising mega-environments, summarizing the patterns of GE interaction of a data set. This graph consists of a polygon with perpendicular black lines, called equality lines, drawn on its sides. When connecting the markers of the genotypes with the seven lines of equality, as illustrated, they divide the GGE-biplot into seven sectors, but the environments are divided into two. In this context, the environments grouped within these sectors are considered similar in relation to the environmental influence generated by the genotypes (YAN; TINKER, 2006).

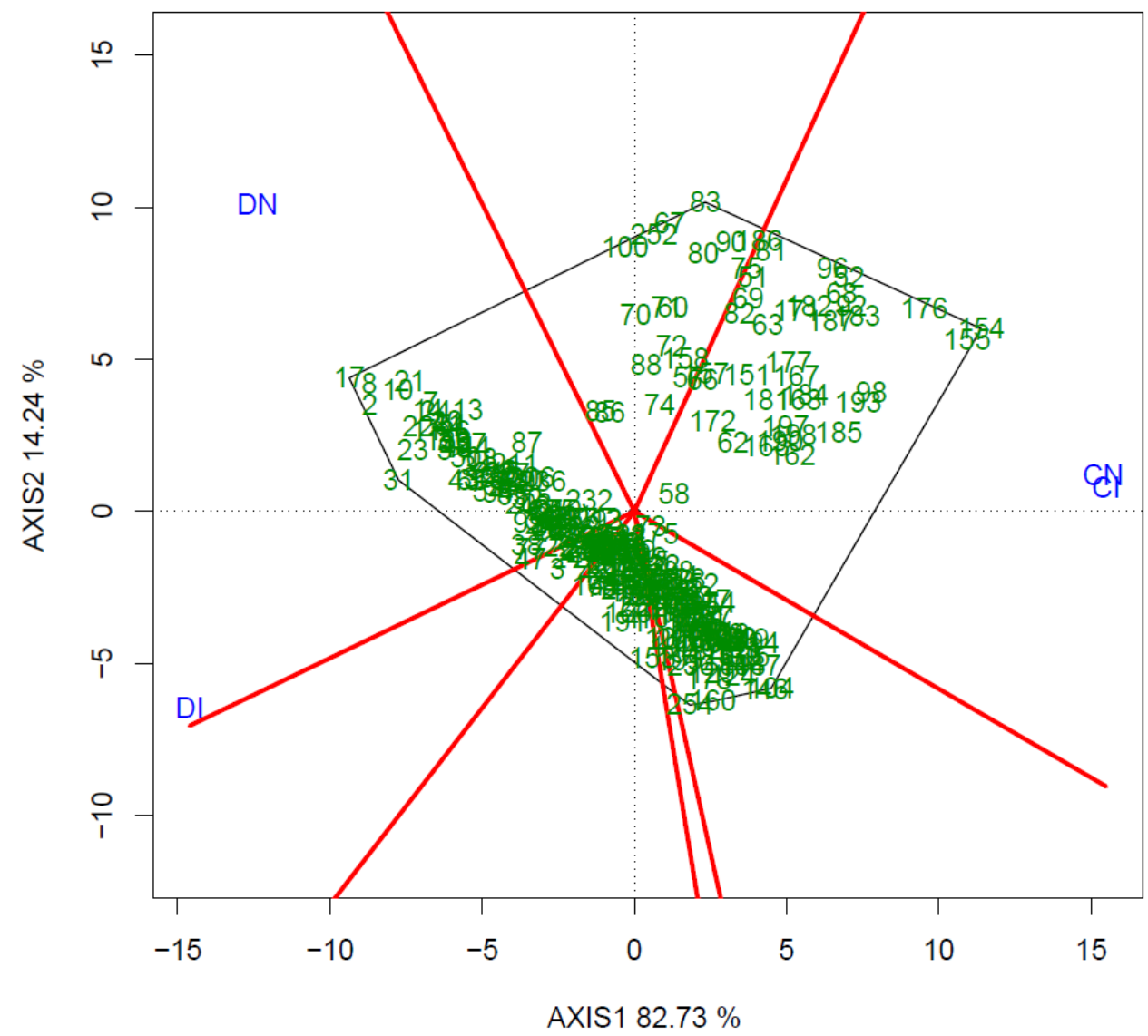

Figure 6. GGE biplot representing the "which won where" graph of the genotype-ideotype selection index (GISI) from 256 genotypes evaluated at Dourados inoculated (DI), Dourados not inoculated (DN), Caarapó inoculated (CI) and Caarapó not inoculated $(\mathrm{CN})$ sites in 2018.

Genotype 17 , located at one of the vertices of the polygon, was the most favorable for DI and DN, and genotype 154 was the most favorable for CI and $\mathrm{CN}$. Thus, it can be inferred that these genotypes were the closest to the ideotype in at least one of the environments and were among the genotypes with better performance in the other environments of the group (YAN; RAJCAN, 2002).

Notably, when genotypes generate vertices of the polygon, but do not contain any grouped environment, they are considered unfavorable to the groups of tested environments, revealing low responsiveness and productivity. In this context, the genotypes located in the sectors are also unfavorable to the recommendation; that is, these genotypes did not have a good association with Azospirillum brasiliense.

For breeding programs, it is important to select genotypes with wide adaptability and stability. In figure 5, the genotypes with these characteristics are those close to the environment axis and its perpendicular axis. In Figure 6, all progenies located in mega-environments with sites represented by inoculation treatment are important for selection. These progenies are important for breeding programs; however, the purpose of this study was to select genotypes that increased yield when inoculated with Azospirillum brasiliense, while evaluating the efficiency of the GGE-biplot method for this selection. 
In Table 2, it can be observed that the highyielding genotypes are not the ones with higher values in the GISI. In addition, according to Oliveira et al. (2014), the visualization of selection indexes in biplot graphs to study genotype adaptability and stability does not select only higher yielding genotypes. Considering this and the need for genetic material that increases their yielding capacity with Azospirillum inoculation, the genotypes' distance to the ideotype is shown in Figure 7.

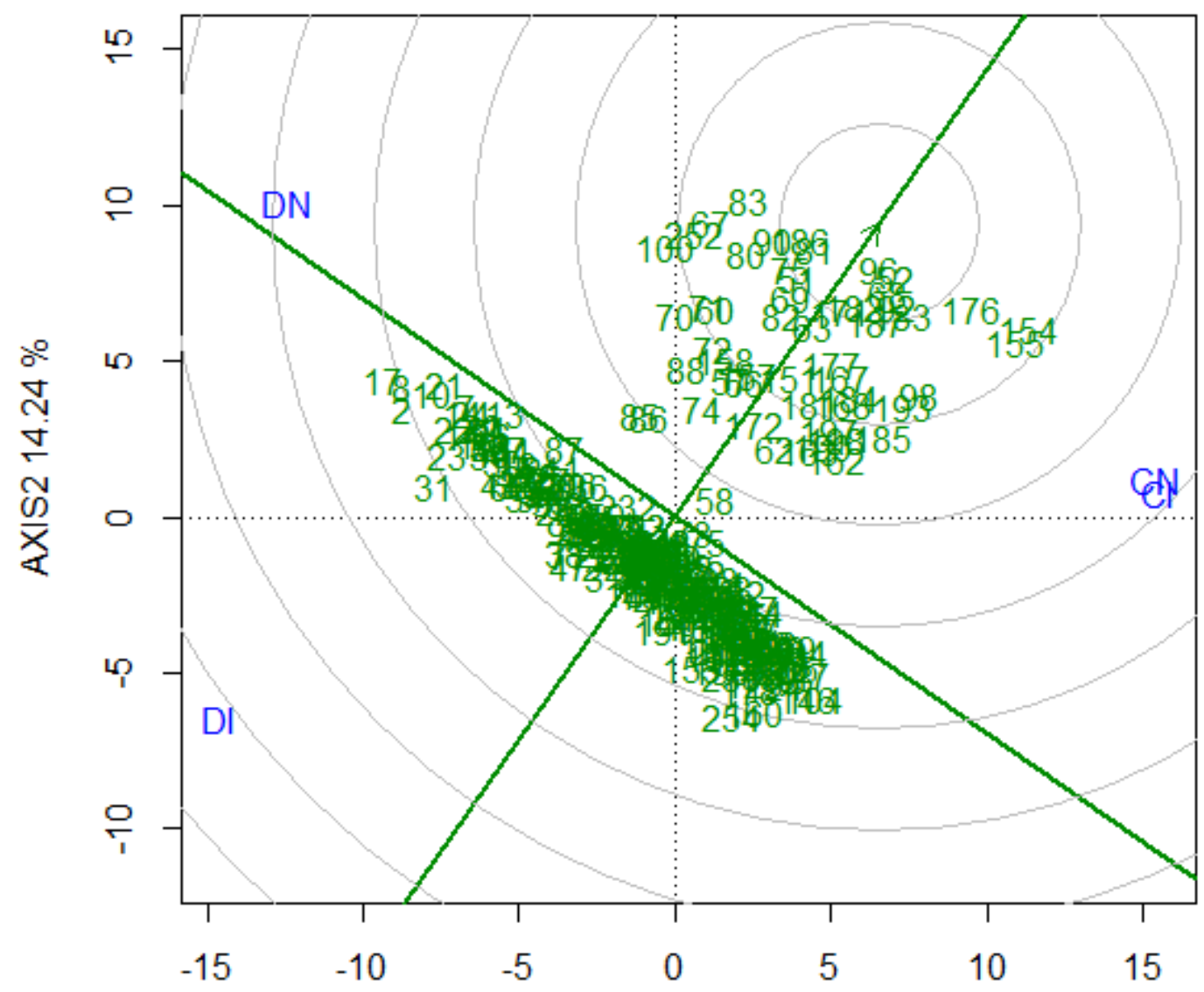

AXIS1 $82.73 \%$

Figure 7. GGE biplot representing the distances of 256 genotypes to the ideotype, evaluated at Dourados inoculated (DI), Dourados not inoculated (DN), Caarapó inoculated (CI) and Caarapó not inoculated (CN) sites in 2018.

An ideal hypothetical genotype, which is located at the center of the concentric circles in Figure 7, has both high mean values of the measured traits and high stability. Ideal genotype projection on the MEA x-axis was designed to be equal to the longest vector of all genotypes. The ideal genotype is stable because its projection on the MEA y-axis is zero. Genotypes were ranked based on their distance from the ideal genotype. Therefore, genotype 96 is characterized as the one with the highest values of the traits used to calculate the GISI, together with stability across the environments. It is located in the smallest concentric circle, together with genotypes $51,52,68,71,75,81,83,86,92,182$, and 187 , representing the group of genotypes closest to the ideotype.

The benefits of efficient plant-bacterial interaction, widely reported in the literature, go beyond nitrogen fixation. Urrea-Valencia et al. (2021) observed that after corn root developed, $A$. brasiliense remained in sufficient concentrations in the rhizosphere, increasing productivity, and enabling the use of this practice in agricultural management.

As the most widely used growth-promoting bacteria in Brazil, Azospirillum can increase plant yield by up to $70 \%$ (CASSÁN; DIAZ-ZORITA, 2016). One of the mechanisms involved, for example, is the morphological and physiological changes in the plant's root system that contribute to greater absorption of water and nutrients (CASSÁN; DIAZ-ZORITA, 2016; URREA-VALENCIA et al., 2021).

Studies on cassava (HRIDYA; BYJU; 
MISRA, 2012) and sesame (SHAKERI et al., 2016) have shown that nitrogen provided by diazotrophic bacteria can partially suppress chemical nitrogen fertilization. This is due to the extensive plantbacteria specificity and genetic adaptation of species in symbiosis over time. Thus, the interaction of Azospirillum brasiliense with maize is not specific or capable of supplying all nutrients to the plant (HUNGRIA et al., 2010).

This study is an initial phase of progeny selection. In this stage, the program seeks to select progenies that increase their grain yield with the inoculation of Azospirillum, and present wide adaptability and stability considering the environmental weather conditions. The 12 abovementioned progenies, located in the first circle in Figure 7, were selected to demonstrate further specific interactions with Azospirillum brasiliense. Thus, the combination of the multivariate index with the GGE-biplot graph facilitated the increase in the specificity of these genotypes with the bacteria, which may reduce their dependence on industrial fertilizers and advance towards sustainability.

\section{CONCLUSIONS}

Progenies 51, 52, 68, 71, 75, 81, 83, 86, 92, 96,182 , and 187 were selected from the present study to demonstrate more specific interactions with Azospirillum brasiliense. The multivariate index observed on the GGE-biplot graph allowed the selection of progenies for efficient association with nitrogen-fixing bacteria.

\section{ACKNOWLEDGEMENTS}

We extend our gratitude to CAPES for financial support, and UFGD's Plant Breeding and Biotechnology Group for labor support.

\section{REFERENCES}

ALBRECHT, S. L. et al. Nitrogen fixation by cornAzospirillum associations in a temperate climate. Crop Science, 21: 301-306, 1981.

ARAUJO, K. C.; VIVAS, M. Multivariate analysis used as a tool to select snap bean (Phaseolus vulgaris L.) genotypes. Australian Journal of Crop Science, 12: 67-73, 2018.

ARAÚJO, L. B. D. et al. Gráficos biplot e joint plot para o estudo da interação tripla. Ciência Rural, 40: 833-839, 2010.

BENDER, S. F.; WAGG, C.; HEIJDEN, M. G. V. D.
An underground revolution: biodiversity and soil ecological engineering for agricultural sustainability. Trends in Ecology \& Evolution, 31: 440-452, 2016.

BERGAMASCHI, $H$. et al. Déficit hídrico e produtividade na cultura do milho. Pesquisa Agropecuária Brasileira, 41: 243-249, 2006.

CASSÁN, F.; DIAZ-ZORITA, M. Azospirillum sp. in current agriculture: From the laboratory to the field. Soil Biology and Biochemistry, 103: 117-130, 2016.

CURÁ, J. A. et al. Inoculation with Azospirillum sp. and Herbaspirillum sp. Bacteria Increases the Tolerance of Maize to Drought Stress. Microorganisms, 5: 1-16, 2017.

FANCELLI, A. L.; DOURADO NETO, D. Ecofisiologia e fenologia. In: FANCELLI, A. L.; DOURADO NETO, D. Produção de milho. 2.ed. Guaíba: Agropecuária, 2000. 360 p.

FERREIRA, D.F. Estatística multivariada. 3 ed. Lavras, MG: Editora UFLA, 2018. 624 p.

HAICHAR, F. Z.et al. Plant host habitat and root exudates shape soil bacterial community structure. The ISME journal, 2: 1221-1230, 2008.

HRIDYA, A. C.; BYJU, G.; MISRA, R. S. Effect of biocontrol agents and biofertilizers on root rot, yield, harvest index and nutrient uptake of cassava (Manihot esculanta Crantz). Archives of Agronomy and Soil Science, 59: 1215-1227, 2012.

HUNGRIA, M. et al. Inoculation with selected strains of Azospirillum brasilense and A. lipoferum improves yields of maize and wheat in Brazil. Plant and Soil, 331: 413-425, 2010.

KHAKWANI, K. et al. Maize ideotype breeding for changing environmental conditions. African Journal of Agricultural Research, 13: 512-517, 2018 .

LONGHINI, V. Z. et al. Nitrogen fertilization and inoculation with diazotrophic bacteria in corn intercropped with xaraés grass. Revista Brasileira de Ciências Agrárias, 12: 340-347, 2017.

MELO, A. V. et al. Divergência genética entre híbridos de milho em condições de deficiência hídrica. Revista de Agricultura Neotropical, 6: 66$75,2019$.

OKOYE, N. F. et al. Seed Production, Growth and Grain Yield of Self, Half-sib and Bulk-sib Progenies Developed from an Early-maturing Maize (Zea mays L.) Population. Asian Research Journal of 
Agriculture, 9: 1-12, 2018.

OLIVEIRA, R. L.et al. Selection index in the study of adaptability and stability in maize. The Scientific World Journal, 2014: 1-6, 2014.

OLIVEIRA, T. R. A. D. et al. The GT biplot analysis of green bean traits. Ciência Rural, 48: 1-6, 2018.

QUADROS, P. D. D. et al. Desempenho agronômico a campo de híbridos de milho inoculados com Azospirillum. Revista Ceres, 61: 209-218, 2014.

RAIJ, B. V. Nitrogênio. In: RAIJ, B. V. (Ed.). Fertilidade do solo e adubação. Piracicaba, SP: Editora Agronômica Ceres, 1981. v. 2, cap. 9, p. 119 $-124$

R CORE TEAM. R: A language and environment for statistical computing. 2018.

SAVEMORE, N. N.; MANJERU, P.; NCUBE, B. Pod yield stability and adaptation of groundnut (Arachis hypogaea L.) genotypes evaluated in multienvironmental trials in Zimbabwe. African Journal of Plant Science, 11: 174-184, 2017.

SHAKERI, E. et al. Improvement of yield, yield components and oil quality in sesame (Sesamum indicum L.) by $\mathrm{N}$-fixing bacteria fertilizers and urea. Archives of Agronomy and Soil Science, 62: 547$560,2016$.

SHARMA, R. C. et al. Identifying high yielding stable winter wheat genotypes for irrigated environments in Central and West Asia. Euphytica, 171: 53-64, 2009.

SOUZA, M. S. et al. Azospirillum spp. from native forage grasses in Brazilian Pantanal floodplain: biodiversity and plant growth promotion potential. World Journal of Microbiology and Biotechnology, 33: 1-13, 2017.

SUN, J. et al. Involvement of glnB, glnZ, and $g \ln D$ genes in the regulation of poly-3-hydroxybutyrate biosynthesis by ammonia in Azospirillum brasilense Sp7. Applied Environmental Microbiology, 68: 985-988, 2002.

URREA-VALENCIA, S. et al. Detection of Azospirillum brasilense by qPCR throughout a maize field trial. Applied Soil Ecology, 160: e.103849, 2021.

USDA - United States Department of Agriculture. World Agricultural Production. Circular series. July-2019. Disponível em: <https:// apps.fas.usda.gov/psdonline/circulars/production.pdf >. Acesso em: 12 de jul. 2019.

VIDOTTI, M. S. et al. Maize responsiveness to Azospirillum brasilense: Insights into genetic control, heterosis and genomic prediction. PloS one, 14: e.0217571, 2019.

VIMAL, S. R. et al. Soil-plant-microbe interactions in stressed agriculture management: a review. Pedosphere, 27: 177-192, 2017.

WICKHAM, H. ggplot2: Elegant Graphics for Data Analysis. New York: Springer, 2010. 213 p.

YAN, W.; FRÉGEAU-REID, J. Genotype by Yield* Trait (GYT) Biplot: a novel approach for genotype selection based on multiple traits. Scientific reports, 8: 1-10, 2018.

YAN, W.; HOLLAND, J. B. A heritability-adjusted GGE biplot for test environment evaluation. Euphytica, 171: 355- 369, 2010.

YAN, W. et al. Cultivar evaluation and megaenvironment investigation based on the GGE biplot. Crop Science, 40: 597-605, 2000.

YAN, W. et al. GGE biplot vs. AMMI analysis of genotype-by-environment data. Crop science, 47: 643-653, 2007.

YAN, W.; TINKER, N. A. Biplot analysis of multienvironment trial data: Principles and applications. Canadian Journal of Plant Science, 86: 623-645, 2006.

YAN, W.; RAJCAN, I. Biplot analysis of test sites and trait relations of soybean in Ontario. Crop Science, 42: 11-20, 2002.

YAN, W. GGEbiplot - A Windows application for graphical analysis of multienvironment trial data and other types of two $\square$ way data. Agronomy journal, 93: 1111-1118, 2001.

YANG, R. C. et al. Biplot analysis of genotype $\times$ environment interaction: proceed with caution. Crop Science, 49: 1564-1576, 2009. 